Secretary of the Congress not later than April 30th, 1953, Abstracts should not exceed 500 words.

\title{
ORGANIZATION AND PROGRAMME OF THE CONGRESS
}

The Sixth International Congress for Microbiology will include:

A. Plenary Sessions. Plenary sessions are planned for the opening and closing sessions and other events of general interest.

B. Sections. A list of the sections will be given in the final programme according to the subjects of the communications received.

The following is a provisional list:

I. General microbiology. (In this final programmethis section will be divided into sub-sections (morphology, metabolism, growth factors, etc.), according to the communications received.)

II. Growth inhibitors (antibiotics, chemotherapeutics, antiseptics).

III. Genetics

IV. Pathogenicity (virulence, toxins).

V. Microbiological technique and diagnosis. (In the final programme this section will be divided into subsections (probably including large scale production of microorganisms, quantitative microbiology, etc.). according to the communications received).

VI. General immunology.

VII. Immunological chemistry.

VIII. Animal viruses. 
Page 6

INTER NATIONAL BULLETIN

XI. Plant viruses.

X. Bacteriophages.

XI. Rickettsiae.

XII. Schizomycetes. (To be divided into sub-sections in the final programme, according to the communications received.)

XIII. Spirochaetes.

XIV. Fungi.

XV. Protozoa.

XVI. Microbe-transmitting arthropods.

XVII. Microbiology applied to human, veterinary and plant pathology.

XVIII. Microbiology applied to agriculture.

XIX. Industrial microbiology and fermentations.

XX. Microbiology applied to hygiene.

XXI. Microbiology of milk and foodstuffs.

C. Symposia. All the lectures at the symposia will be by invitation. They will be organized by the Istituto Superiore di Sanita. The following symposia are planned:

1. Bacterial cytology.

2. Microbial metabolism.

3. Nutrition and growth factors.

4. Growth inhibitors and chemotherapy. 
BACTERIOLOGICAL NOMENCLATURE AND TAXONOMY

5. Morphology, biology and systematics of the Actinomycetales.

6. Host-virus interactions.

D. Meetings of the Special Committees of the International Association of Microbiologists will be called by the Secretary General of the I. A. M. at the proposal of the respective Presidents. Decisions will be submitted for approval at the General Assembly at the closing session of the Congress.

\section{MEETINGS OF JUDICIAL COMMISSION AT THE \\ VI INTERNATIONAL CONGRESS OF MICROBIOLOGISTS}

Most of the agenda to be considered by the International Committee on Bacteriological Nomenclature must be put in form by the Judicial Commission. It is therefore necessary that the Judicial Commission hold a series of meetings before the first meeting of the International Committee, and at least three before the formal opening of the Congress.

Dr. Cowan, one of the Joint Secretaries, has submitted the following proposals for the meetings of the Judicial Commission.

$\begin{array}{ll}\text { Thursday, } & \text { September } 3-9: 00 \text { a.m. } \\ \text { Friday, } & \text { September 4 }-9: 00 \text { a.m. } \\ \text { Saturday, } & \text { September 5 }-9: 00 \text { a.m. } \\ \text { Tuesday, } & \text { September 8 }-3: 30 \text { p.m. } \\ \text { Wednesday, September } 9-2: 30 \text { p.m. }\end{array}$

